\title{
Democracy, Student Movement and Thinking: A Response to Michael A. Peters' Article
}

\author{
Kang Zhao \\ Associate Professor, Department of Educational Studies, College of \\ Education, Zhejiang University, PR China \\ kangzhao@zju.edu.cn
}

\begin{abstract}
In this essay, firstly I agree with Peters on his point that Dewey's political democracy reveals his idea of education as a public good suggested in the newly discovered Dewey's Lectures, and I highlight Dewey's idea of relationship between political democracy and education. Secondly, for Peters' puzzle about Dewey's lack of discussion in this lecture concerning the students' action in the May 4th Movement, I present Dewey's such kind of discussion from another lecture series given at Beijing. Finally, with the notion of "narrative learning", I echo Peters' comment regarding Deweyan mode of thinking as the only way of understanding about thinking.
\end{abstract}

\section{Keywords}

Dewey - political democracy - education - the May 4th Movement - thinking

In his article "100 years of Dewey in China, 1919-1921: A Reassessment", Michael Peters recounts the historical background of Dewey's visit to China 100 years ago based on a myriad of historical materials with his analysis and comments, then he offers a critical assessment of Dewey's Lectures in Social and Political Philosophy delivered in Peking University in 1919. The assessment is conducted lecture by lecture based on the original manuscripts of the lectures that were recently discovered in Beijing by historian Yung-chen Chiang.

In my view, that Peters chose this series of lectures as the basis for his assessment is significant. This series of lectures were delivered for Peking University 
students under the request of $\mathrm{Hu}$ Shi who once audited a similar course at Columbia University given by Dewey during the war years, though Dewey's interest in political philosophy at that time was still in development, even at the time when he arrived in China (Keenan 1977, p. 129). Given the terrible political conditions of newly established Republic in China, Hu Shi hoped that these lectures would introduce Western theories on political democracy to China. Of course, the lecture title seems to have less to do with education and could be easily neglected by educational researchers. One of Peters' main contributions of this article lies in his endeavor to find that there are indeed some important points of Dewey's social and political philosophy that are relevant to education. Also, as Peters mentioned, the existent version of the texts has some translating problem, and even misses many parts, so analyzing the text from original documents is absolutely necessary for checking our current understanding of those lectures concerning Dewey's social and political philosophy.

I agree with Peters on many points in his article. However, given his assessment is quite analytical, I wish to select three points which I think are important for further discussion. First, to me, the most important point that Peters finds and reiterates through the lecture manuscripts is Dewey's view on the relationship between democracy and education, more precisely, between political democracy and education. This point is found by Peters from Lecture XII and he thinks it is a summary of Dewey's famous argument for education as a public good. Peters stresses that "this chapter is by far the most substantive, the clearest written, especially where he engages the Continental traditions to argue for his own pragmatist version of democracy". Historically speaking, Dewey's conception of democracy changed over his lifetime, that is, starting from democracy as "an ethical ideal" (Dewey 1888) with a moral justification, to democracy as "a mode of associated living" with a scientific justification (Dewey 1916), and finally to "democracy as idea of community life itself" (Dewey 1927) based on cultural naturalism. The early conception of democracy was mentioned less later by Dewey when he moved from absolutism to experimentalism. The rest of the two conceptions of democracy are actually the same one which could be seen as Dewey's conception of social democracy. If we read Dewey's work thoroughly, we may find that for Dewey, democracy links with education largely because democratic social life has an educative function, i.e. democratic social life is the optimal environment for individual growth, or for the emergence of the "individualized self" (Dewey 1927). While we may perceive this link between Dewey's conception of social democracy and education, the other two important questions may follow: what is Dewey's view on political democracy, i.e., democracy as a government form, and what is its relationship to education? At any rate, Dewey admits that democracy is also 
a form of government. It is exactly here in this lecture that we can see Dewey offers a clear answer to the questions.

After delineating his theory of political democracy based on three elements (see Peters' paper), Dewey claims, “...the government is an organ or tool for the realization of public interests, the things that men have in common, that affect all in the way they work out, in their consequences..." (Dewey 2015[1919], p. 39). Dewey then stresses, "How this shall be accomplished is scientific rather than a moral matter - the end however is moral and positive, constructive" (ibid). This is a clear demonstration of the public foundation and experimentalist nature of his conception of political democracy. For Dewey political democracy is just one part of his conception of democracy as the whole of community life itself, not an alternative one. As we can see, he immediately integrates his conception of political democracy into his conception of moral and social democracy: "Political democracy thus runs into the broader moral and social democracy" (ibid, p. 40). What is interesting here is that Dewey clearly articulated the relationship between political democracy and education: "The ulterior justification of political democracy, that is of popular government, is its educative effect" (ibid). For Dewey, political democracy has an educative effect, or we may say, it brings about the consequence of its educative function, that is, "its effect in broadening the interests and imagination, in extending sentiments from personal and local family, clique interest, to take in the welfare of the country, producing a public conscience and civic loyalty; and its effect in stimulating thought, ideas and their expression about social matters" (ibid). This echoes Biesta's (2016) argument that Dewey's conception of democratic education is not an educational theory focusing on offering an educational program for democracy, but an account of educative function of his view of democratic life. Peters' quoting and interpreting of this paragraph is important not only because this part is missing in the printed text in Chinese transcription, ${ }^{1}$ but also because it helps further clarify Dewey's thinking concerning the "link" between democracy and education. I think it could even be an important resource and reference to those who find difficulty in understanding the link between democracy and education in Dewey's work. ${ }^{2}$

1 This part of content in this lecture is missing in the text of Chinese transcription. See Dewey, J. (1999[1920]) Dewey's Five Lectures. Chinese version, translated by Hu Shi. Hefei, Anhui Education Press, p. 64.

2 Some philosophers of education have argued that in Dewey's work, it is actually quite difficult to see clearly the link between democracy and education, see, e.g. Oelkers (2000), Stone (2008). 
Secondly, in analyzing Lecture $\mathrm{X}$ in the series, Peters also makes an interesting remark that "I would have thought that having witnessed the May 4th Movement and the on-going protests by students that Dewey would have more to say or that he would have drawn on his experience more systematically. It was an opportunity when Dewey might have drawn on his Chinese experience but he wanders off the topic and talk of moral and physical force in the administration of law". Peters seems to be disappointed at Dewey's silence concerning the May 4th Movement. We do not know why Dewey did not talk about students' movement in this context. However in the Lecture XVI of Lectures on Philosophy of Education, another series of lectures delivered simultaneously at Ministry of Education in Beijing, Dewey did express his ideas on and attitudes to the May 4th Movement. I would like to respond Peters on this point by offering more information based on Chinese transcription of this lecture. Dewey generally expressed a positive comment to the Students Movement, saying that 'students' movement signifies a new awareness, that is, school/university is societal, and it makes contributions not only to local area, a small group, but also to a large group, the country" (Dewey 1999[1920], p. 178). But he also thinks that there are three drawbacks concerning students' (i.e. students') movement: "(1) It was occasional because it occurred incidentally; (2) It was emotional because it was caused by anger; (3) It was passive because it occurred incidentally to prevent a thing from happening" (ibid). He continued, "When the Movement advances, the students gained awareness, realizing education has social responsibility and social function" (ibid). Then Dewey made some suggestions for future action of students: "Moving from the occasional back to the ongoing work, from the emotional back to intellectual thought, and from being passive back to being more active in constructive career" (ibid). Put in a nutshell, Dewey wished that students would be more rational in their participation in and contribution to social reform. Interestingly, his disciple Hu Shi holds quite similar attitudes to the May 4 th Movement. At the end of this series of lectures, Dewey remarks that what he talked in the lectures were not all based on the success of education in the Western world, but also on its failure, and therefore he hopes that Chinese people will avoid those failures and will do better than the West (ibid, p. 179).

Finally, I wish to shift to Peters' critical response to Dewey's epistemological idea that thinking begins in a crisis of some sort that cannot be resolved by existing social conventions. Nowadays, we have become highly preoccupied by the thinking mode of "problem solving" which largely originates from Dewey's pragmatism, and missed alternative ways to understand "thinking". Peters' argument that "theory or thinking may originate in aesthetics and in story-telling" indeed opens alternative avenues to help us understand thinking 
differently. Goodson and his colleagues (2010) have revealed, based on largescale empirical research, that there is a kind of learning going on through storying and from story, which is called "narrative learning". It involves different ways of thinking about our "self" through narrative and action of narrativity, having potential to reconstruct our identity and agency.

In sum, by examining the newly discovered lecture manuscripts that Dewey wrote for Chinese students 100 years ago, Peters made not only an original assessment of Dewey's visit to China, but also an original assessment of Dewey's social and political philosophy in association with Dewey's educational thought. I am impressed with Peters' three insightful points he made in this piece, which trigged my responses by extending, enriching and interpreting them, though I have also learned more from other points in the article.

\section{References}

Biesta, Gert. (2016) Education and Democracy Revisited: Dewey's Democratic Deficit. In S. Higgins \& F. Cofield (Eds.), John Dewey's Democracy and Education. London, UCL IOE press.

Dewey, John (1969 [1888]) The Ethics of Democracy. In J.A. Boydston (ed), John Dewey. The Early Works, 1882-1898. Volume 1: 1882-1888. Carbondale \& Edwardsville, Southern Illinois University Press.

Dewey, John (1966 [1916]) Democracy and Education. New York, The Free Press.

Dewey, John (2015 [1919]) Lectures in Social and Political Philosophy, 1919-21. Symposia. John Dewey's Lectures in Social and Political Philosophy (China), European Journal of Pragmatism and American Philosophy, vII (2) pp. 7-45.

Dewey, John (1999 [1920]) Dewey's Five Lectures. Chinese Version, Translated by Hu Shi. Hefei, Anhui Education Press.

Dewey, John (1952 [1927]) The Public and Its Problems. Chicago, Ill, The Swallow Press.

Goodson, I., Biesta, G., Tedder, M., \& Adair, N. (2010) Narrative Learning. London, Routledge.

Keenan, Barry (1977) The Dewey Experiment in China. Cambridge, Harvard University Press.

Oelkers, J. (2000) Democracy and Education: About the Future of a Problem. Studies in Philosophy and Education, 19, pp. 3-19.

Stone, L. (2008) Speculation on A Missing Link: Dewey's Democracy and Schools.Journal of Educational Controversy, III(1). 